\title{
Knowledge and opinions of child development vocational school students about child neglect and abuse
}

\section{Çocuk gelişimi meslek yüiksekokulu öğrencillerinin çocuk ihmal ve istismarı ile ilgili bilgi düzeyleri ve görüşleri}

\section{Nagihan Yıldız Çeltek ${ }^{1}$, Gülsseren Oktay ${ }^{1}$, Ufuk Ünlüi ${ }^{2}$, Osman Demirr}

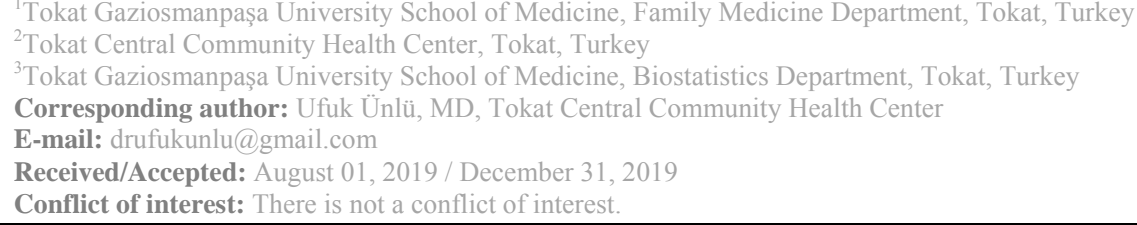

\section{SUMMARY}

Objective: This study was planned in an attempted to find out knowledge and opinions about child neglect and abuse of child development vocational school students who has an important role in the care of 0-6 age group children, and to create an awareness in this field.

Method: Our descriptive type study's sample was formed by 197 Tokat Gaziosmanpaşa University Child Development Vocational School Students. To obtain the data survey form was applied to the students in the classroom in break time between courses. 7 students who were not present in the class were excluded from the study were excluded from the study. In order to data analysis number, percentage, mean, standard deviation and chi-square test were used.

Results: Regarding 190 students who participated in the study, 188 were female and 2 were male. $9.5 \%$ of the students (n: 18) stated that they had been subjected of violence, $13.8 \%$ of (n: 26$)$ stated that they were exposed to neglect. 20 students $(10.5 \%)$ received formal training in neglect and abuse. $93.1 \%$ (n: 175) of the students stated that they had to report child neglect and abuse according to the law, $88.6 \%$ (n: 164) of stated that they should report in accordance with the policies of Ministry of National Education, 95.8\% (n: 181) stated that they were responsible for moral reporting. When they detect neglect or abuse, $47.3 \%$ (n: 88) think that they should report it to Social Services and 39.2\% (n: 73) think that they should report it to the Security Directorate. The rate of those who think they can recognize physical abuse symptoms is $29.1 \%$ (n: 55 ). $94.1 \%$ of the students (n: 176) stated that they needed more information about this subject.

Conclusions: As a result of our study, we found that child development students did not have sufficient knowledge about child neglect and abuse. To increase knowledge level and awareness of child developers who having close contact with children changes in the education program should be planned, and abuse and neglect should be included in the curriculum.

Keywords: Child abuse and neglect, student, child development, knowledge level

\author{
Nagihan Yıldız Çeltek \\ (D) Gülseren Oktay \\ ID Ufuk Ünlü \\ D Osman Demir
}

ORCID IDs of the authors: N.Y.C. 0000-0003-2145-9825 G.O. 0000-0002-2020-6503 U.Ü. 0000-0001-7995-0866 O.D. 0000-0002-1322-2716 
ÖZET

Amaç: Bu çalışma 0-6 yaş grubu çocukların bakımında önemli rolü olan çocuk gelişimi öğrencilerinin çocuk ihmal ve istismarına dair bilgi düzeylerini ve görüşlerini saptamak ve bu alanda bir farkındalık yaratmak amacıyla planlandı.

Yöntem: Tanımlayıcı tipteki çalışmanın örneklemini Tokat Gaziosmanpaşa Üniversitesi Çocuk gelişimi bölümünde okuyan 197 öğrenci oluşturmaktadır. Verilerin elde edilmesi için öğrencilere anket formu ders arasında, sınıfta uygulandı. Anket formlarının uygulandığı derste sınıflarda olmayan 7 öğrenci çalışma dışı bırakıldı. Verilerin analizinde sayı, yüzde, ortalama, standart sapma ve ki-kare testi kullanıldı.

Bulgular: Çalışmaya katılan 190 öğrencinin 188 tanesi kız, 2 tanesi erkek idi. Öğrencilerin \%9,5’i (n:18) şiddete, \%13,8'i (n:26) ihmale maruz kaldığını ifade etmiş̧tir. İhmal ve istismar konusunda resmi bir eğitim alanların sayısı 20 'dir (\%10,5). Öğrencilerin \%93,1’i ( $\mathrm{n}=175)$ kanunlara göre çocuk ihmal ve istismarını bildirmek zorunda olduklarını, \%88.6's1 (n:164) Milli Eğitim Bakanlığı politikaları gereği bildirmeleri gerektiğini, \%95,8'i (n=181) ise ahlaki anlamda bildirimden sorumlu olduklarını ifade etmişlerdir. İhmal veya istismarı tespit ettiklerinde \%47.3'ü (n:88) Sosyal Hizmetlere, \%39,2’si (n:73) Emniyet Müdürlüğüne bildirmesi gerektiğini düşünmektedir. Fiziksel istismar belirtilerini tanıyabileceğini düşünenlerin oranı \%29,1'dir (n:55). Öğrencilerin \%94,1’i (n:176) bu konuda daha fazla bilgilendirilme gereksinimi duyduğunu ifade etmiştir.

Sonuç: Yaptığımız çalışma sonucunda çocuk gelişimi öğrencilerinin çocuk ihmal ve istismarı konusunda yeterli düzeyde bilgi sahibi olamadıklarını saptadık. Çocuklarla yakın temasta olan çocuk gelişimcilerin bilgi düzeylerini ve farkındalıklarını arttırabilmek için eğitim programında değişiklikler planlanması, müfredat programlarında istismar ve ihmal konularına daha fazla yer verilmesi gerekmektedir.

Anahtar sözcükler: Çocuk istismar ve ihmali, öğrenci, çocuk gelişimi

\section{INTRODUCTION}

Child neglect and abuse; it is a problem that affects people, families and society negatively and is important all over the world. The World Health Organization (2016) states that one quarter of adults worldwide are physically abused during childhood; one in 5 women and one in 13 men reported sexual abuse during childhood ${ }^{1}$. By definition, "Child neglect is the failure to meet the needs necessary for the physical, social and emotional development of the child" 2 . The needs for the development of the child are; nutrition, dressing, housing, education, medical care, spiritual support ${ }^{3}$. Child abuse is defined as "the deliberate and unintentional behaviour of parents, other adults, the state and society in a way that prevents the child's physical, social and emotional development" ${ }^{2}$. Various protection programs are being developed to prevent child neglect and abuse. ${ }^{4}$ Despite this, nearly 41,000 children under the age of 15 die every year due to the murder ${ }^{1}$. According to data from the Human Rights Association of Turkey in 2018 also 502 child injured due to abuse/exploitation ${ }^{5}$. It is clear that these numbers are the face of the iceberg. This is because accurate data cannot be obtained because of social concerns, false social beliefs. In this sense, it is important to report in case of suspicion or detection of neglect and abuse. Therefore, the educators working in the educational stage, which has an important place in the development of the child, have important duties.

Graduates of the department of child development are also educators who have the opportunity to work especially in preschool period. Preschool period is a stage in which especially children are more inadequate in terms of self-expression. In this sense, the teacher's observations and the success of detecting different behaviours in the child may vary depending on experience and knowledge. In addition, students with disabilities may be exposed to more maltreatment than nondisabled students, although they cannot be fully demonstrated by studies ${ }^{6}$. In this respect, graduates of child development who are interested in their education should have knowledge about this subject in order to suspect neglect and abuse.

In this study, we aimed to determine the level of knowledge and views of child neglect and abuse of the students studying at the Department of Child Development at Tokat Gaziosmanpaşa University and to raise awareness in this field.

\section{MATERIAL AND METHODS}

The study was planned on 197 students studying at the Child Development Department of Gaziosmanpaşa University in Tokat in 2015. In this descriptive study, it was aimed to reach all the students who were educated in 2015; however, 7 students who were not in the classes were excluded from the study in which the questionnaire forms were applied. The study was conducted between May and June 2015. In order to measure the level of knowledge about child neglect and abuse, a questionnaire that prepared by the researchers by examining the literature was conducted. 
Number, percentage, mean, standard deviation and chi-square test were used for data analysis. Calculations were made with statistical software and $\mathrm{p}$ values less than 0.05 were considered statistically significant.

\section{RESULTS}

Of the 190 students who participated in the study, 2 were male and the others were female. The number of students in the first grade were 88 $(47.3 \%)$ and the number of second grade students were $98(52.7 \%) .70 .5 \%$ of the students had a nuclear family. When the education level of the mother was examined, $57.1 \%$ were primary school graduates and $10.1 \%$ were illiterate. When the educational level of the father was examined, $41.8 \%$ were primary school graduates and there was one illiterate. $95.8 \%$ of the students were single and 6 students had children. $72.6 \%$ of them considered their economic situation as moderate and $1.6 \%$ as bad.

In this study we aimed to determine the level of knowledge and views on child neglect and abuse, $13.8 \%$ of the students stated that they were neglected in childhood and $9.5 \%$ stated that they were exposed to violence. $89.5 \%$ of the students stated that they have not received any formal education about child abuse and neglect / child protection. The rate of those who knew that they had to report the suspicion of child neglect and abuse according to the law was $93.1 \%$. According to national education policies, $88.6 \%$ of students knew they had to report suspicion of child neglect and abuse. In addition, the rate of those who think that they are responsible for reporting in the moral sense was $95.8 \%$. When the answers to the question about to whom do you report neglect or abuse are examined, it is found that the rates of reporting as $47.3 \%$ to Social Services Directorate, $39.2 \%$ to Police Department, $5.9 \%$ to school administration, $3.8 \%$ to school family union, $2.2 \%$ to national education directorate and $1.6 \%$ to health directorate.

$63.5 \%$ of the students stated that they would report physical abuse to the authorities and $62.8 \%$ stated that they would discuss emotional abuse with the family. (Table 1)

Table 1: Status of abuse reporting

\begin{tabular}{|c|c|c|c|}
\hline & & $\mathbf{n}$ & $\%$ \\
\hline \multirow{4}{*}{$\begin{array}{l}\text { What is your attitude if } \\
\text { you encounter any } \\
\text { neglect or abuse? } \\
\text { (Physical) }\end{array}$} & Don’t report & 2 & 1,1 \\
\hline & Report to school administration & 33 & 17,5 \\
\hline & Report to authorities & 120 & 63,5 \\
\hline & Discuss with family & 34 & 18 \\
\hline \multirow{4}{*}{$\begin{array}{l}\text { What is your attitude if } \\
\text { you encounter any } \\
\text { neglect or abuse? } \\
\text { (Emotional) }\end{array}$} & Don't report & 17 & 9 \\
\hline & Report to school administration & 18 & 9,6 \\
\hline & Report to authorities & 35 & 18,6 \\
\hline & Discuss with family & 118 & 62,8 \\
\hline \multirow{4}{*}{$\begin{array}{l}\text { What is your attitude if } \\
\text { you encounter any } \\
\text { neglect or abuse? } \\
\text { (Sexual) }\end{array}$} & Don't report & 1 & 0,5 \\
\hline & Report to school administration & 11 & 5,9 \\
\hline & Report to authorities & 143 & 76,1 \\
\hline & Discuss with family & 33 & 17,6 \\
\hline \multirow{4}{*}{$\begin{array}{l}\text { What is your attitude if } \\
\text { you encounter any } \\
\text { neglect or abuse? } \\
\text { (Neglect) }\end{array}$} & Don't report & 14 & 7,4 \\
\hline & Report to school administration & 11 & 5,9 \\
\hline & Report to authorities & 52 & 27,7 \\
\hline & Discuss with family & 111 & 59 \\
\hline
\end{tabular}

The rate of those who think they can recognize physical abuse symptoms is $29.1 \%$ (n: 55 ). $94.1 \%$ (n: 176) of the students stated that they needed more information about this subject. $52.9 \%$ of the students stated that they were informed about child protection law.

\section{DISCUSSION}

Child neglect and abuse is an important problem that can cause both mental and physical problems.
It is clear that the bad event will leave deep traces not only at that moment but also in the whole life of the child. It can affect the child's interactions, school success and professional career. The World Health Organization reports that one in four adults has been physically abused in childhood ${ }^{1}$. In our country, it is reported that approximately five hundred children were injured in the last year due to abuse ${ }^{5}$. However, whether this reflects the actual data remains as a question mark in the 
minds. So considering that the actual data is above these numbers, the result is frightening.

In this study, which was carried out to determine the level of knowledge of child development students about child neglect and abuse, 9.5\% of students stated that were exposed to violence in their childhood and $13.8 \%$ were neglected. In another study on high school students, about $10 \%$ of students reported that they were exposed to violence ${ }^{7}$. In a different study conducted on a total of 365 people including health workers, teachers and students, $8.6 \%$ of the health professionals, $6.4 \%$ of the teachers and $6 \%$ of the students reported that they were exposed to abuse at some point in their lives ${ }^{8}$.

It is clear that the mistreatment will leave deep traces in the child's life. Healthy generations mean healthy and strong societies. In this respect, it is important for both the individual and the society to prevent child neglect and abuse. In this sense, health professionals and educators who are in contact with children have an important duty; recognizing negligence and abuse and making necessary notifications are both a moral and legal obligation. Article 279 of the Turkish Penal Code states that when a public official learns of an offense, he will be sentenced to six months to two years' imprisonment if he does not report it to the authorities ${ }^{9}$. Person or people suspected of abuse may report directly or via call centers to the nearest law enforcement agencies, prosecutor's office and Provincial Directorates of the Ministry of Family and Social Policies ${ }^{10}$.

The majority of child development students felt that they had to report child neglect and abuse according to laws (93.1\%) and National education policies $(88.6 \%)$, and the vast majority were also responsible for reporting them morally $(95.8 \%)$. Regarding the question Whom do you report when you find child neglect and abuse, they answered as to the social services directorate $(47.3 \%)$ and to the police department $(39.2 \%)$. In a study conducted on teachers, $84.4 \%$ of the teachers knew that reporting of child neglect and abuse was a legal obligation and $98 \%$ thought that it was necessary to declare conscientiously ${ }^{11}$. In a similar study conducted on the teachers working in Afyonkarahisar, most of the teachers knew that reporting was both a legal $(85.9 \%)$ obligation and that they had to make a moral (97.6\%) notification. In the same study, the question Whom do you tell was answered by teachers to the school administration (56\%) in the first place and to the social services directorate $(21.2 \%)$ in the second ${ }^{12}$. Consequently, the obligation to make a notification is generally known, but it is thought that there is confusion about the information to whom it should be notified.

Graduates of child development are a group working especially during preschool education. It is important that recognizing of child neglect and abuse by the child development graduates who working in period when children are inadequate to express themselves. In this study conducted on students studying in the child development department of our university, $29.1 \%$ thought that they could recognize the symptoms of physical abuse. In addition, most students (94.1\%) indicated that they needed more information on child neglect and abuse. In another study conducted in Ankara, 31 out of 38 teachers $(81.6 \%)$ stated that they wanted to receive training in this subject ${ }^{13}$. In the study conducted on teachers in Rize, $84.5 \%$ of the teachers stated that they found their knowledge about abuse inadequate ${ }^{14}$. Since educational institutions are the place where children spend the most time after the family, it is thought-provoking topic which is both teachers and students who will become child development specialists feel inadequate.

\section{CONCLUSION}

We found that child development students do not have sufficient knowledge about child neglect and abuse. In this respect, it is thought that the lack of information can be prevented by arranging education curricula and maintaining the continuity of information through in-service trainings.

\section{REFERENCES}

1. World health organization. Child maltreatment. https://www.who.int/en/news-room/factsheets/detail/child-maltreatment.Erişim tarihi:9.07.2019.

2. T.C Milli Eğitim Bakanlı̆̆ı. Aile ve Tüketici hizmetleri. İhmal ve istismar. Çocuk istismar ve ihmali. Ankara. p4-5.

3. Marcdante KJ, Kliegman RM. Çocuk istismarı ve ihmali. Yurdakök M, çev.ed. Nelson Pediatrinin Temelleri. 7. Baskı. Ankara: Güneş Tip Kitabevleri; 2017.p70-75.

4. Yılmaz EB. Çocuk istismarının önlenmesinde kullanılan programlar ve özellikleri. Anadolu Hemşirelik ve Sağlık Bilimleri Dergisi, 2013;16 (4):255-259.

5. İnsan hakları derneği. 2018 Türkiye insan hakları ihlalleri bilançosu. file://C:/Users/qwerty/Desktop/\%C3\%87OCUK $\% 20 \%$ C4\%B0ST\%C4\%B0SMAR/2018IHDYillik Rapor_Bilanco\%20kaynak\%204.pdf. erişim tarihi:09.07.2019 
6. İnsan hakları derneği. Çocuk İstismarı ve İhmali: Tanımlar ve Göstergeler. Çocuk İhmali ve İstismarını Önleme öğretmenler ve aileler için eğitim k1lavuzu. Ankara: Berkay ofset. Aralık 2008.p 3-23.

7. Özgür G, Yörükoğlu G, Arabacı LB. Lise Öğrencilerinin Şiddet Algıları, Şiddet Eğilim Düzeyleri ve Etkileyen Faktörler. Psikiyatri Hemşireliği Dergisi 2011;2(2):53-60.

8. Bağla AG, Arıkan M, Kılıç RÖ, Orulluoğlu F, Kuyucu İ, Özğan M ve diğerleri. Sağlık çalışanları, öğretmenler ve üniversite 1. sınıf öğrencilerinin çocuk istismarı ve ihmali ile ilgili bilgi düzeylerinin değerlendirilmesi. Balıkesir sağl1k bilimleri dergisi 2017; 6(1): 1-10.

9. Türk ceza kanunu. (2004). T.C Resmi Gazete, 25611, 2/10/2004

10. T.C. Aile ve sosyal politikalar bakanlığı. Çocuk hizmetleri genel müdürlüğü. Cinsel İstismar Mağduru Çocuklarla İlgili Adli Süreç. Çocuk Bakım Kuruluşlarında Çalışan Personele Yönelik İstismar ile mücadele rehber kitapçı̆̆ 1 . p17
11. Sağır M, Gözler A. Sınıf Öğretmenlerinin Çocuk İstismarı ve İhmaline Yönelik Görüşleri ve Farkındalık Düzeyleri. OPUS-Türkiye Sosyal Politika ve Çalışma Hayatı Araştırmaları Dergisi 2013 Aralık; 3(5): 67-102

12. Ahu Kürklü (2011). Öğretmenlerin çocuk istismarı ve ihmaline yönelik farkındalık düzeyleri. Yüksek lisans tezi, Afyon Kocatepe Üniversitesi, Afyon.

13. Dilsiz H, Mağden D. Öğretmenlerin çocuk istismar ve ihmali konusunda bilgi ve risk tanıma düzeylerinin tespit edilmesi. Hacettepe Unıversity Faculty of Health Sciences Journal 2015; 1 ( No Supp12): 678-694.

14. Yıldız Y, Kaçar M, Albayrak E, Çalaboğlu T, Çakmak S, Bayraktar T. Çocuk İhmali ve İstismarı Hakkında İlköğretim Öğretmenlerinin Bilgi Düzeylerinin Değerlendirilmesi. Van Tip Dergisi 2017; 24(4): 303-309. 